\title{
ANALYSIS OF ORGANIZATIONAL CULTURE IN SUGAR FACTORY: A CASE STUDY OF PT PG RAJAWALI II
}

\author{
Mirzandiko Bayu Ramadhani*, Najib Mukhamad, Djohar Setiadi \\ School of Business, Bogor Agricultural University, Indonesia \\ *E-mail: bayuramadhanimirzandiko@gmail.com
}

\begin{abstract}
Sugar in Indonesia is included in strategic staple food commodities. The level of sugar production and consumption in Indonesia from 2009 to 2016 has increased annually. However, the increase in consumption is not matched by the amount of production. PT PG Rajawali II is a company engaged in the sugar industry. PT PG Rajawali II has four sugar factories namely PG Sindang Laut, PG Tersana Baru, PG Jatitujuh, and PG Subang. This study aims to analyze the current organizational culture and expectation of the employees in the future. This study used a survey of Organizational Culture Assessment Instrument (OCAl) method. The result of this research is the difference of organizational culture on every PG under PT PG Rajawali II. The current organizational culture of PG Sindang Laut and PG Subang is a clan. Meanwhile, it is a hierarchy in PG Tersana Baru and PG Jatitujuh. Organizational culture expected to be dominant in PG Sindang Laut, PG Jatitujuh, and PG Subang is a hierarchy. Meanwhile, it is the market in PG Tersana Baru. This description of the organizational culture profile can be used as input for PT PG Rajawali II as the parent company to make policy which is compatible with the company's vision and mission to make better performance for PG.
\end{abstract}

\section{KEY WORDS}

Organizational culture, factory, quantitative description, performance.

The organization is an institution or place that people use to cooperate in achieving organizational goals effectively and efficiently. According to Robbins (1994), the organization is a consciously coordinated social unit with an identifiable boundary. It works on the basis of groups to achieve a common goal. The organization is led by a person and has a systematic structure. Vision, mission and common goal are one of the aspects of forming an organization. Wibisono (2006) argues that vision is a sentence that contains the ideals of an organization or company in the future. Meanwhile, the mission is a sentence that states the purpose of the organization and contains what is provided by the company to the community, whether in the form of product or service. The organization is considered good if its existence can contribute to the surrounding community.

According to Koentjaraningrat (2002), culture is the unity of idea, action and the work of human beings in the framework of the life of society that turns into human self-owning through learning. Culture is an integral part of human life and passed down from generation to generation. Culture is compelling and contains rules about what to do and not to do. A strong culture gives encouragement to the people within it to act in accordance with what is determined by the organization. Culture is the framework used to organize one's activities.

Similar to a human being, every organization has an identity. What is meant by identity is an organizational culture. According to Hasibuan (2011), the organization is a formal, structured, and coordinated union system of a group of people working together to achieve a particular goal. The organizational culture varies for each company. Organizational culture can be the key to a company's excellence if its organizational culture is embraced in accordance with the company's mission and vision. Proper organizational culture also has the effect to improve employee performance by creating a comfortable environment.

PT PG Rajawali II is a subsidiary of PT RNI (PERSERO) engaged in the sugar industry. There are four sugar factories owned by PT PG Rajawali II namely PG Sindang Laut, PG Tersana Baru, PG Jatitujuh and PG Subang. The overall sugar factory is located in West Java, 
Indonesia. PT PG Rajawali II has the vision to become one of the best sugarcane companies in Indonesia with a strong financial structure and environmentally friendly.

The business development in the sugar industry and the high demand for sugar products force PT PG Rajawali II to continuously improve the company's performance. In reality, the company suffered the loss from 2012 until 2016. The loss of the company can be indicated that the company's performance was not good. One of the factors influencing the company performance is organizational culture. The problem with PG under PT PG Rajawali II is the changing policy of every change of leadership, lack of clarity of blueprint and long-term plan on $P G$, and no transition at the time of change of position. Basically, the company wants all employees to run their activities in accordance with the vision, mission, and corporate organizational culture. But in practice, the culture invested by the company is often ignored by employees. Furthermore, there is resistance to the organizational culture that exists in the company. Ivancevich, Konopaske, and Matteson (2006) argue that strong fear, anxiety, and rejection are due to the greater changes in human structure, task, technology, and asset.

Based on the background and the formulation of the above problem, the purpose of this study is to analyze the current organizational culture profile in PT PG Rajawali II and analyze the organizational culture profile expected in PT PG Rajawali II.

\section{LITERATUR REVIEW}

Organizational culture. According to Sutrisno (2013), organizational culture can be defined as a system of value, belief, assumption or norm that have long been accepted, agreed upon, and followed by members of an organization as a code of conduct and problem-solving organization. The above statement is similar to Kusdi's (2011) statement that organizational culture is the patterns of behavior, attitude, value, and the assumption that have been socialized by members of an organization to new members and somewhat stable over time. According to Mangkunegara (2007), organizational culture is an assumption or system of belief, value, and norm developed within the organization as a guide of behavior for all members of the organization to address the problem of external and internal adaptation. According to Siagian (2002), organizational culture is a common perception among all members of the organization about the essential meaning of life collectively. Meanwhile, according to Robbins \& Judge (2013) organizational culture is the study of what people do in an organization and how their behavior can affect the performance of the organization. Luthans (2010) states that organizational culture is the understanding, prediction, and management of human resources within the organization.

Thus, it can be deduced from some of these definitions that the organizational culture is a system containing value, belief, and norm that are believed and executed by all members of the organization concerned with the purpose as a guideline of behavior, solving the problems of external and internal organization, and also about the essential meaning of life collectively. The organizational culture within an organization will vary with each other. However, the organizational culture will show certain feature, trait, or characteristic that will show its similarity.

Function of Organizational Culture. The function of culture is difficult to distinguish from organizational culture because it is a social phenomenon. The organizational culture of a company or organization has several functions. According to Robbins (1996), there are five functions of organizational culture as follows:

- Culture creates a clear distinction or limit between one organization and another;

- Culture provides a sense of identity for the members of the organization;

- Culture facilitates the emergence of organizational commitment rather than individual interests;

- Culture as a social adhesive to help unify the organization;

- Culture as a control mechanism that guides and shapes attitude and behavior of employees.

Kreitner and Kinicki (2005) divide the four functions of organizational culture namely: 1) As the giver of organizational identity to the employees; 2) Facilitate collective commitment; 3 ) 
Provide social system stability; 4) Help to shape the behavior so that members can be aware of their environment

Based on these functions, it can be concluded that organizational culture has a positive function and also has an important role in achieving organizational goals. Culture is very useful in eliminating ambiguity among the employees because culture can strengthen the organization. Cultures can also inform the employees on how the work should be done and that the employees' thought is important. Organizational culture also has a function as a giver of identity, help to set limits in socializing, as well as generating employees' commitment.

Organization Culture Typology. Cameron and Quinn (in Kusdi 2011) develop cultural typology into four cultural dimensions based on competing values framework, among others:

1. Clan Culture. Organizational culture is characterized by a fun workplace such as a big family. The leadership of this culture is considered to be a mentor, even some people already like a father figure. The adhesive in this organization is loyalty and tradition. This type of organization gives great attention to the development of the people within as well as the importance of togetherness and morale. Success in this type of culture is shown when employees feel happy because they become part of the organization and can also show a sensitivity to the consumers. Participation, teamwork, and opinion are key in this type of culture.

2. Adhocracy Culture. This organizational culture is characterized by a dynamic and entrepreneurial workplace. In this type of culture, the brave leader takes risks as well as acting as an innovator. The adhesive in this organization is a commitment to the opportunity to experiment and innovate continuously. Success in this culture can be seen if they succeed in creating new and unique products that make them appreciate the innovation more. This culture deeply appreciates employees' freedom and initiative.

3. Market Culture. This organizational culture is characterized by a results-oriented workplace. In this type of culture, leaders usually have a hardworking nature emphasizing on achievement. The adhesive in this organization is the desire to win the competition. Employees are very concerned about the reputation of the organization and also a strong desire to beat the competitors. Success in this type of culture is seen by how much market share and how strong the market penetration of their products.

4. Hierarchy Culture. This organizational culture is characterized by a formal and structured workplace. In addition, the culture of this organization also greatly emphasizes the importance of good and neat structure in the organization. The model or management guideline used usually centers on tight control. The leader in this type of culture is usually a person who can be a coordinator or organizer who also prioritizes the efficiency in all fields. Success in this culture is seen from how timely the work schedule is completed, how low the costs are incurred, and how reliable the output is.

Competing values framework has six variables representing four cultures. The six variables are processed into questions that include: (1) dominant character, (2) leadership type, (3) management type, (4) adhesive organization, (5) strategy emphasis, and (6) success criteria.

\section{METHODS OF RESEARCH}

This study used Organizational Culture Assessment Instrument (OCAI) analysis. OCAI analysis is done by spreading the questionnaire. On the questionnaire sheet that had been provided, the respondents were asked to give a score on each of the existing cultural dimension based on the current and desired conditions. The OCAl analysis aims to assess four types of organizational culture containing six key dimensions of organizational culture. The four types of cultures are clan, hierarchy, adhocracy, and market. Based on this analysis, it can be known what culture stands out today and what is desired in an organization. After knowing the prominent culture, the management can use the data as a consideration in determining the appropriate strategy with the existing culture. Each culture has a different strategy for improving the quality of the organization. According to Kusdi (2011), there are two stages in the preparation of OCAI. First, the six cultural dimensions are operationalized into measurement variables that are divided into two parts: the current culture and the desired culture. Secondly, 
each dimension is revealed to be a cumulative question indicator that will result in a score and will be used to indicate the position of an organization in the four quadrants of organizational culture.

This research was conducted in four PG under PT PG Rajawali II, namely PG Sindang Laut, PG Tersana Baru, PG Jatitujuh, and PG Subang in West Java. This research was conducted in August 2017 - November 2017. This research used purposive sampling with the aim of obtaining samples that have the desired characteristic or criteria such as having the position of general manager and head of the section on a PG. With this sampling method, it is expected that the results can describe the real state of organizational culture.

\section{RESULTS AND DISCUSSION}

The organizational culture profile of all PG Rajawali II is seen using the OCAI questionnaire on different value graphs, which are currently perceived and desirable in the future.

The OCAI analysis on Sindang Laut PG was conducted at the manufacturer of general manager and also on the section head. The results of OCAI analysis on PG Sindang Laut can be seen in Figure 1.

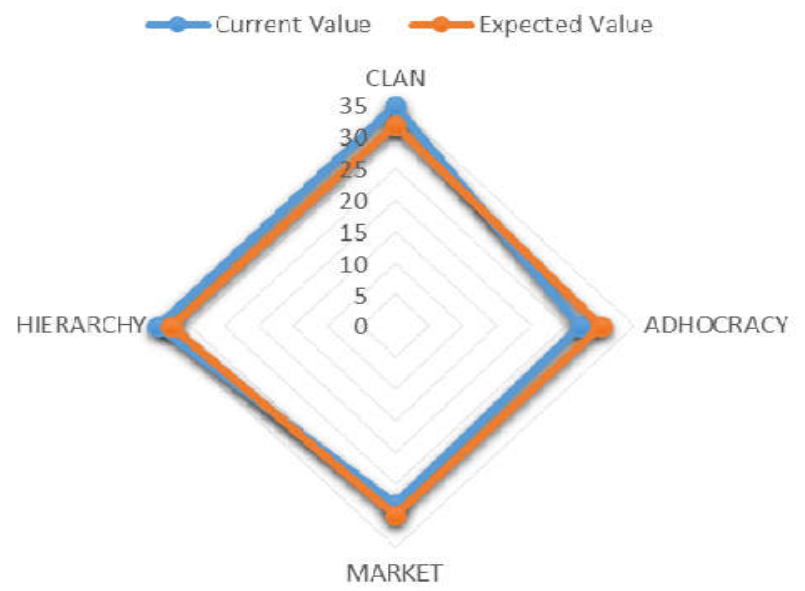

Figure 2 - The results of OCAl analysis on PG Sindang Laut

Based on Figure 2, the results of OCAI PG Sindang Laut analysis can be seen that the graph of the current value with Clan value $=34.925$, Adhocracy $=27.125$, Market $=28.23$, and Hierarchy $=34.71$. As for the expected value graph obtained Clan value $=31.83$, Adhocracy $=$ 30.11 , Market $=29.83$, and Hierarchy $=32.75$. From the graph, it can be concluded that the current value is more dominant to clan culture. Clan culture can be interpreted that the existing organizational culture has a good teamwork with mutual trust. Thus, the relationship exists between the leadership and employees are like family.

Change is what expected from the analysis of organizational culture expected of the employees and leaders of PG Sindang Laut. The expected organizational culture is dominant hierarchy culture. The hierarchy organizational culture character is a structured and controlled place. The desired type of leader is someone who can be a coordinator and oriented towards the efficiency. A type of management that can provide a sense of security and relationship stability. An organization's adhesive that contains formal rule and policy. The emphasis of the strategy is more on efficiency, stability, control, and fluency. The criterion of success in the hierarchy culture is the efficiency for the welfare of employees in it which can be achieved.

The OCAI analysis on New PG Tersana was done at the manufacturer of general manager and also to the section head. The results of OCAI analysis on PG Tersana Baru can be seen in Figure 2. 


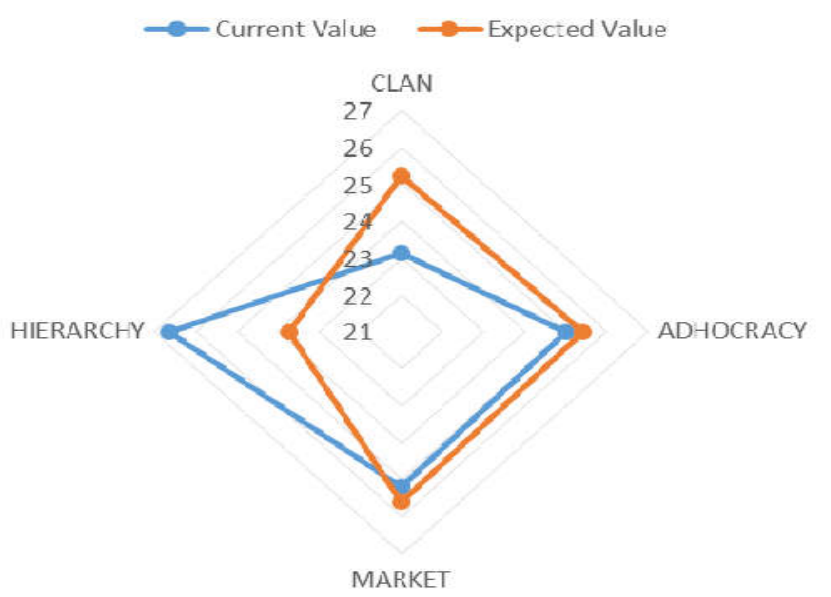

Figure 3 - The results of OCAI analysis on PG Tersana Baru

Based on Figure 3, the OCAI PG Tersana Baru analysis results above can be seen that the graph of the current value with Clan value $=23.125$, Adhocracy $=25$, Market $=25.2$, and Hierarchy $=26.67$. As for the expected value graph obtained Clan value $=25.2$, Adhocracy $=$ 25.41, Market $=25.625$, and Hierarchy $=23.75$. From the graph, it can be concluded that the current value is more dominant to the hierarchy organizational culture. The cultural hierarchy can be interpreted that a culture puts production efficiently with the aim of prospering employees and the leader of the organization. The hierarchy culture has a structured and controlled place character with a management type that can provide a sense of security.

The analysis of organizational culture expected of employees and leaders of PG Tersana Baru is the creation of dominant culture to market culture. The market culture has a character that is oriented towards a goal with an aggressive and results-oriented leadership type. Competitive management type and have high demands on achievement. The adhesive of the organization in this culture is the achievement of good results. The criterion of success is when a company wins the competition or becomes a leader in a competitive market.

The OCAI analysis on PG Jatitujuh was performed at the manufacturer of general manager and also on the section head. The results of OCAl analysis on PG Jatitujuh can be seen in Figure 3.

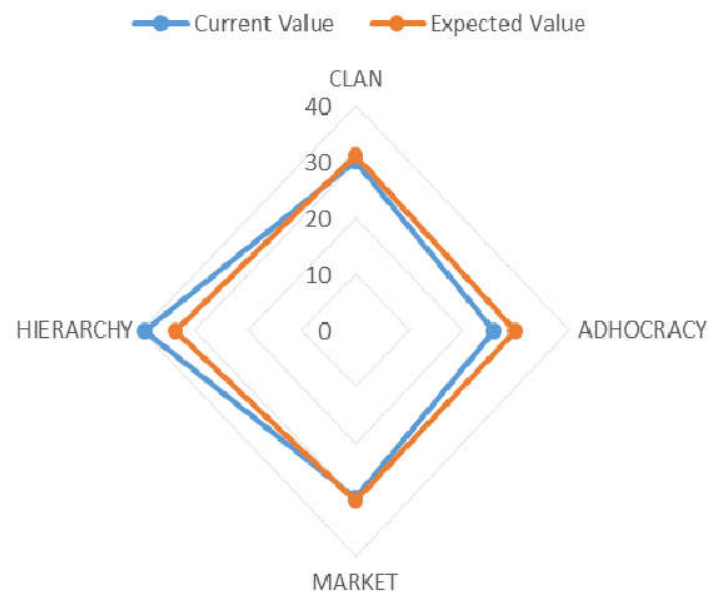

Figure 3 - The results of OCAI analysis on PG Jatitujuh

Based on Figure 3, the results of OCAI PG Jatitujuh analysis above show that the graph of the current value with Clan value $=30.08$, Adhocracy $=25.8$, Market $=29.62$, and Hierarchy $=39.4$. As for the expected value graph obtained Clan value $=31.15$, Adhocracy $=29.91$, Market $=30.14$, and Hierarchy $=33.79$. From the graph, it can be concluded that the current value is more dominant in the hierarchy culture. The hierarchy organizational culture character 
is a structured and controlled place. The desired type of leader is someone who can be a coordinator and oriented towards efficiency. A type of management that can provide a sense of security and relationship stability. An organization's adhesive that contains formal rule and policy. The emphasis of the strategy is more on efficiency, stability, control, and fluency. The criterion of success in the hierarchy culture is the efficiency for the welfare of employees in the organization that can be achieved.

The analysis of organizational culture expected of employees and leaders of Jatitujuh PG is that no change to be made which means staying as the dominant in hierarchy culture. Employees and leaders of PG Jatitujuh can feel the culture existing today and they expect it to be as they wish. The emphasis on production efficiency for the achievement of welfare for all those in PG Jatitujuh is the key in order for PG Jatitujuh to get out of an unfavorable position. Negative gains in every sugarcane harvest season arrive as a basis for the company to be more efficient and effective in carrying out its operational activities.

The OCAI analysis on PG Subang was performed at the manufacturer of general manager of the plant and also to the section head. The results of OCAI analysis on PG Subang can be seen in Figure 4.

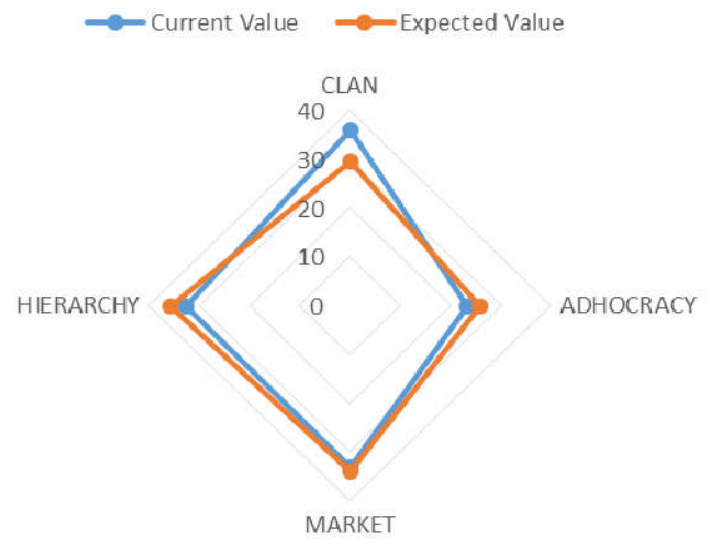

Figure 5 - The results of OCAI analysis on PG Subang

Based on Figure 4, the result of OCAI PG Subang analysis above shows that the graph of the current value with Clan value $=28.54$, Adhocracy $=19.79$, Market $=25.2$, and Hierarchy $=$ 26.45. As for the expected value graph obtained Clan value $=23.95$, Adhocracy $=22$, Market $=$ 26.95 , and Hierarchy $=27.08$. From the graph, it can be concluded that the current value is more dominant in clan culture. Culture clan can be interpreted that the existing organizational culture already feels like family with good teamwork and mutual trust.

The analysis of organizational culture expected of employees and leaders of Subang PG produce is the dominant culture toward the culture of hierarchy. The hierarchy organizational culture character is a structured and controlled place. The desired type of leader is someone who can be a coordinator and oriented towards efficiency. A type of management that can provide a sense of security and relationship stability. An organization's adhesive that contains formal rule and policy. The emphasis of the strategy is more on efficiency, stability, control, and fluency. The criterion of success in the hierarchy culture is the efficiency for the welfare of employees in the organization that can be achieved.

\section{CONCLUSION AND SUGGESTIONS}

Based on the results of research and discussion on the analysis of organizational culture using Organizational Culture Assessment Instrument (OCAI) on PG under the auspices of PT PG Rajawali II namely PG Sindang Laut, PG Tersana Baru, PG Jatitujuh, and PG Subang. By using descriptive quantitative, then obtained the following conclusion: 
- The currently dominant cultural profile of PG Sindang Laut and PG Subang which is Clan namely culture like family, the emphasis of strategy on human resource development, and good cooperation success criteria.

- The currently seen as the dominant cultural profile of PG Tersana Baru and PG Jatitujuh is Hierarchy namely formal culture, an organizational character that is structured, and success criterion is efficiency.

- The cultural profile of PG Sindang Laut, PG Jatitujuh, and PG Subang in the future is Hierarchy culture. This culture focuses on a structured and controlled place, an efficiency-oriented type of leadership, a type of management that can provide a sense of security or relationship stability. The formal policy is something that tackles the organization, emphasize the strategy on efficiency and stability, and success criteria is low-cost production.

- The profile of PG Tersana Baru culture to be desired in the future is the market culture. This culture is goal-oriented, has an aggressive leadership type with competitive management type. The adhesive of the organization in this culture is the achievement of good results. The strategy emphasis on achieving the target and the success criteria is to be a leader in a competitive marketplace.

Based on the results of the discussion and conclusions that have obtained, the suggestions that can be given in an effort to create an appropriate organizational culture on PG under PT PG Rajawali II are as follows:

- General Manager as a leader in every PG is expected to have a culture in accordance with the vision and mission of the company. Thus, the transfer of culture to employees can be carried out appropriately.

- In the overall organizational, Clan and Adhocracy cultures become culturally expected for some PGs. Some PGs prefer the company as big family, but some other PGs want a more dynamic and entrepreneurial company.

\section{REFERENCES}

1. Hasibuan, Malayu S.P., 2011. Manajemen Sumber Daya Manusia. Bumi Aksara, Jakarta.

2. Ivancevich, Jhon M. Konopaske, Robert \& Matteson, Michael T, 2006. Perilaku dan manajemen organisasi. Jakarta : Erlangga.

3. Koentjaraningrat. 2002. Pengantar Ilmu Antropologi. PT. Rineka Cipta, Jakarta.

4. Kreitner dan Kinicki. 2005. Perilaku Organisasi. Jakarta : Salemba Empat

5. Kusdi. 2011. Budaya Organisasi: Teori, Penelitian, dan Praktik. Jakarta: Salemba Empat.

6. Luthans, Fred. 2010. Organizational Behavior, "An Evidence-Based Approach". 12th edition. McGraw Hill. New York.

7. Mangkunegara. 2007. Manajemen Sumber Daya Manusia Perusahaan. Bandung: Remaja Rosdakarya.

8. Robbins. Stephen P. 1994. Teori Organisasi Struktur, Desain, dan Aplikasi. Jakarta: Arcan.

9. Robbins. Stephen P. 1996. Perilaku Organisasi, Konsep, Kontroversi dan Aplikasi. Edisi Keenam. Jakarta: PT.Bhuana IImu Populer.

10. Robbins, Stephen P \& Judge, Timothy A. 2013. Organizational Behavior Edition 15. New Jersey: Pearson Education.

11. Siagian S. 2002. Manajemen Sumber Daya Manusia. Yogyakarta: PT Bina Aksara.

12. Sutrisno, H. Edy. 2013. Budaya Organisasi. Jakarta: Kencana Prenada Media Group.

13. Wibisono, Darmawan. 2006. Manajemen Kinerja, Konsep, Desain, dan Teknik.

14. Meningkatkan Daya Saing Perusahaan. Jakarta. Erlangga. 